\title{
Establishment and Growth of Business Clusters with Public Aid
}

\author{
Skokan Karel, Poledniková Eva, Staničková Michaela
}

\begin{abstract}
Industry or business clusters have become a part of an industrial policy in most countries not only within the European Union and are considered an effective instrument for the growth of firms and regional competitiveness. Their development is promoted and supported by many financial schemes at regional, national and even supranational level. The development of industry clusters in Czechia has had a very short tradition so far as the concept of clusters has become known here only at the beginning of this century. Surprisingly public aid for cluster development was approved at the governmental level very soon and the top-down approach strategy followed. The objective of the paper is to identify the basic phases of cluster development in the Czech Republic and to describe the impact of public financing on cluster establishment and growth in Czech regions. The presented case of Moravia-Silesia shows the cluster dynamics in the region which made the use of EU structural funds efficient for their development.
\end{abstract}

Key words: industry cluster, regional development, public aid, structural funds

\section{INTRODUCTION}

Cluster phenomenon has become inevitable part of public economic policies in many countries throughout the world since the 1990s. The outbreak of business clusters in different industries was accompanied by the detailed cluster analyses and various theoretical approaches which resulted in national cluster policies.

The Czech Republic belongs to the advanced countries among new EU members in this field. The cluster development in the Czech Republic can be divided into two stages (Skokan, 2011). The first stage covers the years 2002-2006, in which the cluster concept was presented in the Czech professional literature, to the public authorities at both the national and regional levels and to company managers in industries with clustering potential. It includes also the announcement of first cluster programme called CLUSTERS supported from the EU Structural funds for the search for prospective clusters and their establishment in the first programme period 2004-2007. The second stage covers the years 2007 up till now (2012), when the established clusters developed or new clusters appeared and gained the access to public funds offered by the programme COOPERATION funded by the EU structural funds in the EU programming period 2007-2013. In the paper we present the evaluation of public aid provided for cluster development in both stages.

The paper has the following structure. After Introduction and Objectives and methodology it describes in chapter three the theoretical background for cluster development and policies. The next chapter analyses main milestones in the cluster development in the Czech Republic and describes both the stages of cluster establishment and development from the funding point of view. 
Then the discussion about the clustering processes and financing in NUTS 3 regions follows and the achieved results are presented. Last chapter summarizes the key findings of cluster development in Moravia Silesia region which was considered as old industrial region in the past and has become the leader in cluster support. In the end conclusions are derived from the analysis.

\section{OBJECTIVES AND METHODOLOGY}

Generally, the process of cluster development comprises the two main stages: cluster identification i.e. detailed industry analysis or the "search for clusters", and cluster mobilization, i.e. cluster establishment, cluster strategy preparation and development including joint cluster activities. The first stage aims at finding those industries which are currently competitive or with at least some cluster characteristics, the second refers to the establishment and development of a concrete cluster within the defined industry. In the paper we present the evaluation of public aid provided for cluster development in both stages.

The objective of the paper is to analyze the basic phases of cluster development in the Czech regions and to describe the impact of public financing on cluster formation stemming mostly from EU structural funds. Comparison of cluster establishment in Czech self-governing regions is presented and the way of financing different types of cluster projects concerning cluster search, cluster establishment and cluster development is outlined and discussed. The case of MoraviaSilesia region is presented in detailed as the leading clustering region in the Czech Republic. The key findings from cluster financing by public aid are summarized in a conclusion.

The paper is based upon author's own experience, who participated in cluster development mainly during the first stage and in the first cluster study in North Moravia and Silesia. The information is gained from the programme documents - Operational Programmes (MIT, 2003; MIT, 2010) and official public documents on clusters. The data for evaluation of cluster projects financing were derived from public data on clusters (CzechInvest, 2011) and from internal databases provided by the CzechInvest to the author.

\section{THEORETICAL BACKGROUND FOR CLUSTERS}

Industry clusters as specific form of networked organisations in a given industry and territory have become very popular tools of economic policies mainly in the last two decades. The first ideas on firms clustering were presented by the concept of industrial districts already in the end of 19th century by A. Marshall (1920). However only recently in the 1990s clusters started to be incorporated into the public economic policies in many countries throughout the world. The outbreak of industry clusters in different industries was accompanied by the detailed cluster analyses and various theoretical approaches which resulted in national cluster policies. The modern ages of clusters is closely connected with Michael Porter who described in his work Competitive advantage of nations (1990) the tight relationship between cluster participation and the competitiveness of firms and industries and proposed the first cluster definition, very often criticized and improved later by many authors. By him clusters are geographic concentrations of interrelated companies, specialized suppliers, etc. in similar sector as well as related institutions. Porter's theory of clusters has become the standard concept and was further elaborated by many 
followers. Critical view to this theory was presented by Martin and Sunley (2003) who argue for cautious use of the notion and grant this definition rather chaotic. A Report prepared by expert group of European Commission (2005, p. 9) describes clusters in accordance with Porter as "groups of independent companies and associated institutions that are collaborating and competing; geographically concentrated in one or several regions, even though the cluster may have global extensions; specialized in a particular field, linked by common technologies and skills; either science-based or traditional; cluster can be either institutionalized or non-institutionalized". Alongside with clusters we often refer to cluster initiatives as organized efforts to enhance competitiveness of clusters involving private industry, public authorities and/or academic institutions (Sölvell et al., 2003). Clusters are expected to bring benefit not only to their business members but to the regions they operate in and to universities as well. Firms in clusters can be more specialized and can better cooperate than in isolation. They can also reach the higher level of innovation due to the knowledge spill-over in a proximity, clusters also stimulate the new start-ups, etc. Cluster activities cover many joint actions in areas of networking, human resources and training, research and development, marketing, internationalization, financing and others (Pavelková a kol., 2009). Clustering enables to increase the competitiveness of clusters and the regions they operate in.

There are many ways how clusters emerge, however we can distinguish two basic approaches. The first business driven is the approach bottom-up by which clusters are results of entrepreneurship and networking activities of firms; the second top-down approach is the result of public economic policies focused to cluster establishment, development and support often denoted as cluster policy. Generally the cluster policy is an intersection of different policies. The most important of them are by OECD (2007) regional policy, science and technology policy and industrial and entrepreneurship policy. Cluster policies in EU offer a wide ranges of Community or national and regional programs and initiatives which offer various forms of cluster financing. Since 2000 European Commission launched many initiatives focused to cluster development support, e.g. European Cluster Alliance in 2006, European Cluster Observatory in 2007, European Cluster Excellence Initiative, World Class Clusters (EC, 2010). The financial support was also incorporated in the main programming documents for the EU period 2007-2013 as were the Strategic guidelines on cohesion or Competitiveness and Innovation Framework Programme (2007-2013).

Financing clusters plays very important role mainly in the early stages of their lifecycle (emerging clusters) and can take many different forms mostly as the combination of public/private sources (Bialic-Davendra, 2011). Financing is needed for implementation of joint cluster projects and for operational expenditures of managing cluster organizations. Private sources are either own sources of cluster members as regular membership fees or bank loans, risk capital, business angels or FDI. Public sources cover regional or national budgets and EU funds. We distinguish open-end or temporary public financing which is expected after 3-5 years of cluster operations. The Czech Republic started with cluster initiatives only about ten years ago. The theoretical justification of clusters in the Czech professional literature appeared in parallel with the preparation of the first Czech CLUSTERS (KLASTRY) programme developed from industrial and enterprise policy. It was announced, managed and monitored by the CzechInvest (National Investment and Business Development Agency) within the Ministry of Industry and Trade. As the 
clusters were quite new for the most of future participants there was a demand for information about the clusters. The first works in Czech language were written by the author (Skokan, 2002; Skokan, 2004) who presented results of the first cluster study in North Moravia and Silesia and their role in the regional development and regional innovation systems. Then followed papers about the methods of cluster identifications, e.g. Žizka (2004) or about the role of clusters in the knowledge economy (Šimon, 2005) and their role in strengthening the regional competitiveness (Viturka, 2007; Pavelkova, Jirčíková, 2008). Contemporary streams of theories in the Czech and the Slovak literature are focused on measuring cluster performance and its evaluation (Pavelková a kol., 2009) and assessment of their impact upon regional innovation and development (Szekely, 2008; Kovárník, Stejskal, 2009, Skokan, Poledníková, 2011). At the European level, many overviews and reports of cluster policy support in EU member states are carried out within initiatives of European Cluster Alliance, European Cluster Observatory (EC, 2007; EC, 2008; EC, 2010). There are also papers dealing with the relationships between public policy and the development of industrial clusters in the EU (McDonald et al., 2006; Sölvell et al., 2011; Martin et al., 2011).

\section{DEVELOPMENT OF CLUSTER POLICIES IN THE CZECH REPUBLIC}

The development of clusters and cluster policies in the Czech Republic is closely linked to EU planning period and the public aid given in the form of EU structural funds (Skokan, Poledníková, 2011).

\subsection{Development of cluster policies}

The CzechInvest, a former governmental agency for foreign direct investment launched the pilot project "Feasibility Study to Identify Industry Groupings in Moravia-Silesia for Targeted Aid Scheme Support" in 2002 (Thorburn et al., 2012). The project was financed by EU Phare Programme which gave priority to the lagging old industrial region. The objective of the project was to analyse industries with a potential for clustering and to find out the attitudes of regional actors and firms for cooperation in cluster initiatives. In the project the method for identification of the industry groupings in the region based on location quotient was developed and tested and eight industry groupings, potential clusters were identified. The process was accompanied by company interviews and discussion in focus groups.

Based on the results of the project prepared by the group of foreign and local experts the Cluster Development Programme - CLUSTERS was designed and incorporated into the prepared Operational Programme Industry and Enterprise (OPIE) for the period of 2004-2006 financed by EU structural funds after the Czech Republic admission to the EU (MIT, 2003). It was funded by the European Regional Development Fund in a total amount of $€ 348$ mil. This financial aid was divided into three priorities: Business environment development, Development of enterprise competitiveness and Technical assistance. The initial amount of 9 mil. CZK (approx. 360 thousand $€$ ) was allocated to the CLUSTERS Programme for the period 2004-2006 with planned implementation of at least ten projects of established clusters until 2008. In the end the allocation was increased to $€ 9$ mil. CzechInvest was entrusted to develop and manage the 
support for the cluster initiatives in the Czech Republic. After the first call for projects were announced followed the training of cluster facilitators, cluster concept promotion in the regions, national cluster conferences and preliminary analysis of cluster potential in the whole Czech Republic. The National Cluster Strategy was adopted by the Czech government in July 2005 and The National Cluster Study (Cluster mapping project) was delivered in 2005-2006 as the basis for future cluster development in new Structural funds period 2007-2013. All of this has been accompanied by cooperation of universities, businesses and public regional and national authorities following the model of Triple Helix.

The aim of the first cluster programme CLUSTERS (2004-2008) was to initiate infrastructure for entities which, under certain conditions, group together in order to generate the competitiveness they need in the form of a cluster, i.e. with the integral participation of the region, the tertiary or research sphere, and business entities. The specific objective was to support the groups of companies and associated institutions in two types of projects: (1) Search for companies suitable for association in clusters, assessment of viability and benefits of clusters. The result should be the feasibility study which proves the cluster establishment in both the specific industry and the region. (2) Establishment and development of clusters and fulfilment of their mission was the second type of supported project which followed the first one. For the first type project 42 applications were approved, in the second type project 12 established clusters were supported by public funds. The conditions for subsidy in cluster establishment project were to group at least 15 organizations including one higher education or research institute and $60 \%$ of SMEs. By the end of 2008 there were more than 30 existing clusters in the Czech Republic, the majority of them (9) were established in Moravia and Silesia Region (MIT, 2003).

Second cluster programme (2007-2013) was announced within the Operational Programme Enterprise and Innovation and is running currently as a part of so called COPERATION Programme focused on support for establishing and developing cooperative industry groups. The overall objective of the Programme is to provide support for establishing and developing cooperative industry associations - clusters, centres of excellence, technology platforms and cooperative projects at regional, supra-regional and international levels as a tool for boosting competitiveness of the economy and economic growth. The objective is (MIT, 2010, p. 66): "to create infrastructure for cooperation of enterprises, scientific, research and educational institutes and the communal sphere at the regional and supra-regional level and international cooperation of new and existing groupings and the type of projects include identification, establishment and development of clusters". Cluster activities shall be focused on development of innovations and international competitiveness. From this point of view, clusters shall have permanent links to the research and development base and educational facilities. The subsidy was limited to CZK 3-80 mil. In two calls for projects in 2009 and 2010 total 23 projects were approved for public aid. The last call was announced for 2012.

\subsection{Financing clusters by the programme CLUSTERS}

The aim of the programme CLUSTERS was to support establishment and development of branch groupings on regional and cross-regional level. The results of the programme are summarised in Table 1. 
Tab.1 - Cluster projects and their financing in 2004-2006. Source: Internal CzechInvest database, own processing

\begin{tabular}{|c|c|c|c|c|c|c|}
\hline \multirow[b]{2}{*}{ Region } & \multicolumn{3}{|c|}{ Number of projects } & \multicolumn{3}{|c|}{ Funding (000 CZK) } \\
\hline & $\begin{array}{l}\text { Search } \\
\text { for Clus- } \\
\text { ters }\end{array}$ & $\begin{array}{c}\text { Establish- } \\
\text { ment of } \\
\text { Clusters }\end{array}$ & $\begin{array}{c}\text { Ap- } \\
\text { proved } \\
\text { projects }\end{array}$ & $\begin{array}{l}\text { Search for } \\
\text { Clusters }\end{array}$ & $\begin{array}{c}\text { Establish- } \\
\text { ment of } \\
\text { Clusters }\end{array}$ & Total \\
\hline Jihočeský & 6 & 1 & 7 & 4920 & 9540 & 14460 \\
\hline Jihomoravský & 8 & 3 & 11 & 5971 & 37837 & 43808 \\
\hline Karlovarský & 4 & 0 & 4 & 2696 & 0 & 2696 \\
\hline Královéhradecký & 5 & 3 & 8 & 4507 & 90323 & 94830 \\
\hline Liberecký & 1 & 0 & 1 & 431 & 0 & 431 \\
\hline Moravskoslezský & 8 & 4 & 12 & 6183 & 56511 & 62694 \\
\hline Olomoucký & 1 & 0 & 1 & 882 & 0 & 882 \\
\hline Pardubický & 2 & 0 & 2 & 1760 & 0 & 1760 \\
\hline Plzeňský & 1 & 0 & 1 & 690 & 0 & 690 \\
\hline Středočeský & 1 & 0 & 1 & 664 & 0 & 664 \\
\hline Ústecký & 0 & 0 & 0 & 0 & 0 & 0 \\
\hline Vysočina & 1 & 0 & 1 & 810 & 0 & 810 \\
\hline Zlínský & 3 & 1 & 4 & 2170 & 4913 & 7083 \\
\hline Total & 41 & 12 & 53 & 31684 & 199124 & 230808 \\
\hline
\end{tabular}

The beneficiaries of aid were regions, tertiary education institutions or research organizations, and business entities based in the Czech Republic at outside Prague which was not eligible for this form of public aid.

CLUSTERS Programme has become very popular after its announcement. Of eighty five submitted applications the most projects were in the regions Moravskoslezský (17) and Jihomoravský (13). As it is clear from Table 1, these regions are also leaders in approved projects. In the first type of projects the programme supported 41 "Search" projects which resulted in the feasibility study for clusters. This meant that in the region and the selected industry branch there was a potential for cluster establishment. Total subsidy for the search for clusters was CZK 31.7 mil, the average for the project (feasibility study) was CZK 772 thousand. Only one region, Ústecký, did not apply for the grant. As it follows from the internal database of CzechInvest the majority of applicants were SMEs (16), regional development agencies (8), innovation centres (5) and universities (5). The grants were approved in 2005 for 12 applicants and in 2006 for the 29 applicants.

In the second type of projects the programme supported establishment and development of 12 clusters, the leader became the region Moravskoslezský (4 clusters) followed by regions Jihomoravský (3) and Královéhradecký (3) which received the highest subsidy of almost CZK 95 mil. An average subsidy for establishment and development of a cluster was CZK 16.7 mil., however it ranged from CZK 4.8 mil. (Wood cluster in Moravskoslezský region) to CZK 43.4 mil. (Omnipack packaging cluster in Královehradecký region). These differences explain the leading position of Kralovéhradecký region as for the amount of subsidies. While in the first type of projects only one region did not apply for subsidy, in the second type of project clusters in only five regions applied for grants. 
From the regional point of view the distribution of cluster projects in the regions is very uneven. As it was mentioned, the highest number of project applications in the CLUSTERS programme in 2005-2006 was submitted in Moravskoslezský region followed by Jihomoravský region. The explanation lies in the fact that the cluster concept was known and promoted best in Moravia and Silesia where the first pilot study on clusters was developed in 2002 and there were keen promoters of clusters at the VŠB-Technical University and in the Regional Development Agency (RDA) which belong to the driving forces of the region's transformation. The second position of Jihomoravský region follows from the fact the region is the most innovative region in the Czech Republic. Driving forces of its development are RDA, Universities and mainly South Moravian Innovation Centre which applied for the first cluster projects. Surprisingly no project application was submitted in Ústecký region, the second old industrial type region in the Czech Republic. However, the higher differences between regions are in the development of identified clusters. Only in 5 regions the identified clusters made use of financing their development from the Programme with the same leaders as for Search phase.

\subsection{Financing clusters by the programme COOPERATION}

The goal of the current programme is to create a favourable business environment, improving conditions for business activities and innovation as well as developing a competitive advantage thanks to the improved quality of ties between research, higher education institutions and the business sector (Adámek et al., 2009). The results of the programme in 2009-2011 are summarised in Table 2.

Tab. 2 - Supported cluster by Cooperation Programme. Source: CzechInvest database, own processing

\begin{tabular}{|l|c|r|}
\hline Region & $\begin{array}{c}\text { Number } \\
\text { of cluster } \\
\text { projects }\end{array}$ & $\begin{array}{c}\text { Funding } \\
\text { (000 CZK) }\end{array}$ \\
\hline Jihočeský & 1 & 79996 \\
\hline Jihomoravský & 6 & 241393 \\
\hline Karlovarský & 0 & 0 \\
\hline Královéhradecký & 3 & 121625 \\
\hline Liberecký & 2 & 34409 \\
\hline Moravskoslezský & 6 & 173702 \\
\hline Olomoucký & 1 & 18544 \\
\hline Pardubický & 0 & 0 \\
\hline Plzeňský & 0 & 0 \\
\hline Středočeský & 2 & 28530 \\
\hline Ústecký & 0 & 0 \\
\hline Vysočina & 1 & 28480 \\
\hline Zlínský & 1 & 5939 \\
\hline Total & 23 & 732618 \\
\hline
\end{tabular}


The programme is planned for the programme period 2007 - 2013. Three calls for projects were opened since the beginning of the programme. In the first call announced in 2009 the support was given to 19 clusters with total amount of CZK 683 mil., in the second call announced in 2010 the next 4 clusters were supported with the amount of CZK 50 mil. The third call has not been closed yet. The average subsidy was CZK 31.8 mil. per cluster and it ranged from CZK 4.4 mil. (CzechBio cluster in Středočeský region) to almost CZK 80 mil. (Omnipack cluster in Královéhradecký region). Out of 23 supported cluster projects there are eight clusters which received the support repeatedly in both programmes, i. e. in CLUSTERS programme (2007) and in COOPERATION programme (2009) as well. One cluster in Liberecký region (CLUTEX, cluster of technical textiles) received subsidy for two of its projects. Only four regions out of thirteen eligible for this programme did not apply and receive the subsidies for their clusters.

\subsection{Summary to financing the Czech cluster policy}

The cluster policy in the Czech Republic was initiated after its admission to the EU due to access to EU Structural funds which enabled financing of cluster initiatives. The policy was supported by two cluster programme.

The CLUSTERS programme of 2004 launched the cluster epoch in the Czech Republic. While majority of projects were focused on cluster identification, the COOPERATION Programme of 2009 financed only the development of established clusters.

Both programmes supported in total 76 projects, the programme CLUSTERS subsidied 53 cluster projects, the COOPERATION program 23 projects. The highest number of approved applications were in Moravskoslezský region (18), followed by Jihomoravský region (17) and Královéhradecký region (11). Except of Ústecký region the grants were allocated unevenly to all Czech regions. The decisive impact on cluster development in the Czech Republic had the projects for cluster establishment.

Figure 1 describes the distribution of development projects in the Czech regions which were supported either by CLUSTERS Programme or by COOPERATION Programme. Total number of supported projects was thirty five, twelve of them in the first programme, twenty three in the second programme. Out of the 13 regions only four did not receive any support. The leader is still the Moravskoslezský region with the 10 supported project followed again by Jihomoravský region (9 projects) and Královéhradecký region (6 projects). 


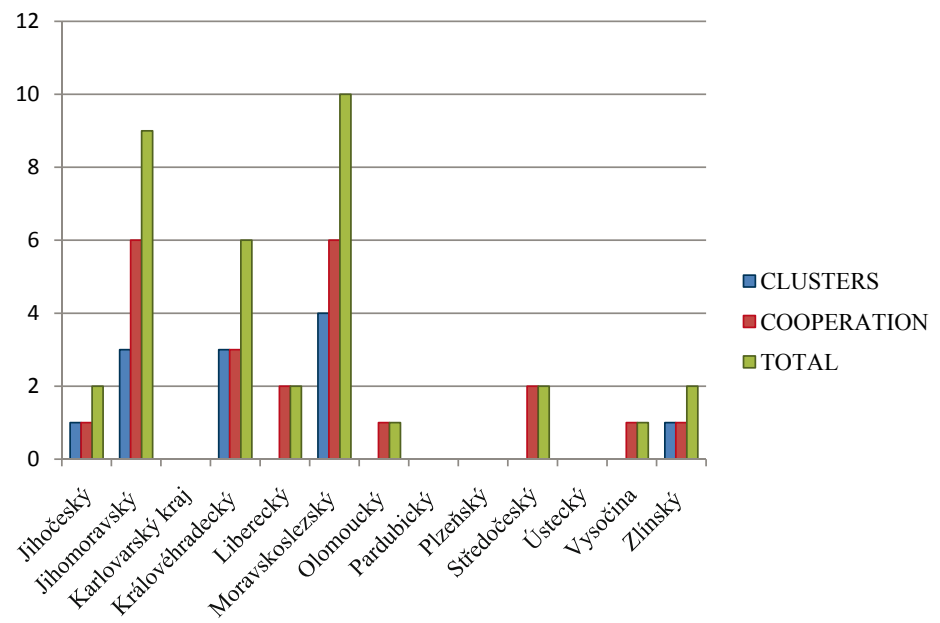

Fig. 1 - Development clusters projects by programme. Source: Own processing by CzechInvest database

As it follows from Table 1 and Table 2, the total amount of subsidies for clusters provided by the two programmes CLUSTERS and COOPERATION between 2005-2010 achieved the amount CZK 963 mil. The amount devoted to the cluster search and identification in CLUSTERS programme was only CZK 32 mil., i.e. $3.3 \%$ of the total. The vast majority of funds were allocated to the cluster development projects which are focused predominantly on innovation. Again, the distribution of these funds is very uneven in the regions. Only 9 out of 13 eligible regions received the subsidy for their clusters with three predominant leaders which became regions Jihomoravský (29.6 \% of total aid), Moravskoslezský (24.5 \%) and Královéhradecký (22.5\%). The subsidies for other regions lie below $10 \%$.

\section{CLUSTER DEVELOPMENT IN MORAVIA SILESIA}

The Moravia Silesia region in the Czech Republic as the most populous region (1.3 mil. inhabitants) lying in the north-east of the country near Slovak and Polish borders was labelled as an old industrial region after the transition to market economy in the 90's. Formerly it was the region with a huge concentration of mining, metallurgy and heavy industries known under the name the steel hart of the country. Its restructuring was very painful and in the last two decades it resulted in the decline of employment in mining from about hundred thousand employees to about twenty thousand and in metallurgy in a similar way (Suchacek, 2005). The unemployment at the beginning of the century was growing very fast and reached more than $16 \%$ in 2004 (Skokan, 2011).

The region was identified by the Czech government the priority regions and a number of regeneration projects were launched in the near past including establishment of Regional Development Agency (RDA), Science Technology Park, Industrial Zones Programme and FDI support and co called "cluster approach" which was launched here more than ten years ago. 


\subsection{Development of cluster policy in Moravia Silesia}

The restructuring of Moravian-Silesian Region after 2000 is marked by huge inflow of foreign direct investment and by the development of clusters in traditional industries such as engineering and wood industry and also in new industries the most important being automotive, ICT and new energy sources (Skokan, 2011). In fact, already before 1989 under communist regime the main metallurgical, mining and heavy industries were clustered in the region with their headquarters, main suppliers and also with a specific VŠB-Technical University offering the education at faculties of mining, engineering, metallurgy and business and economics.

The new era of cluster development started in the region as a joint initiative of Czech Investment agency CzechInvest and VSB-Technical University of Ostrava supported by the Moravian Silesian Regional Authority. The region was the first Czech region to carry out a study identifying clusters (Thorburn et al., 2002), and then established the first cluster in the country - the Moravian-Silesian Engineering Cluster (2003) which was later transformed into national Czech machinery cluster. Main stages of this development which was strongly influenced and supported by regional authorities and by the financial aid from EU Structural funds are given in Table 3.

Tab. 3 - Main phases of cluster development in Moravia Silesia. Source: own processing

\begin{tabular}{|c|l|}
\hline Year & Action \\
\hline 2002 & $\begin{array}{l}\text { Pilot project "Identification of industry grouping for state aid sup- } \\
\text { port in North Moravia Silesia" }\end{array}$ \\
\hline 2003 & $\begin{array}{l}\text { Establishment of first Czech cluster "Moravian Silesian Engineering } \\
\text { cluster" }\end{array}$ \\
\hline $2004-2005$ & Search for clusters in Moravia-Silesia (identification phase) \\
\hline 2006 & Regional initiative ClusterNet in Morava-Silesia \\
\hline $2005-2008$ & $\begin{array}{l}\text { Establishment of 8 regional clusters in Moravia Silesia (CLUSTER } \\
\text { Programme) }\end{array}$ \\
\hline 2008 & Czech National Cluster Association \\
\hline $2009-2012$ & $\begin{array}{l}\text { Development of established regional clusters (COOPERATION } \\
\text { Programme) }\end{array}$ \\
\hline
\end{tabular}

The cluster development in the region is the outcome of effort and initiatives of both the national and regional actors. At the national level they were Ministry for Industry and Trade and the CzechInvest-Investment and Business Development Agency who prepared and managed the cluster programmes. At the regional level they were Moravian Silesian Regional Administration, Union for the Development of the Moravian Silesian region (UDMS), Regional Development Agency Ostrava (RDA) and VŠB-Technical University of Ostrava (VŠB-TU) which is a member of the majority of MS clusters.

The main clusters - machinery, IT and automotive are remarkable for a high number of their members over fifty which proves the changing sector structure in the region towards new industries. After ten years as a result of its highly developed industrial base, extensive education system and range of initiatives supporting research and development, the Moravian Silesian region has become the Czech leader in utilizing the cluster concept to support the local development of key 
economic sectors. Today, clusters form an integral pillar of the region's future industrial development, and provide a key support for the growing competitiveness of the region as a whole. Establishment of cluster is also accompanied by new FDI in modern industries such as TietoEnator in ICT which created about 1800 new jobs and Hyundai in automotive industry with 3000 new jobs in their new assembly plant in Nošovice and further 10000 jobs in suppliers. The overview of clusters in the MS region according to the year of foundation and current number of members can be seen in Table 4.

Tab. 4 - Regional clusters in Moravia Silesia. Source: own processing

\begin{tabular}{|c|l|c|c|c|}
\hline Nr. & Cluster & Established & Members & University \\
\hline 1. & $\begin{array}{l}\text { Czech Machinery Cluster (MS } \\
\text { engineering cluster) }\end{array}$ & 2003 & 58 & $\begin{array}{c}\text { VŠB-TU Ostrava, } \\
\text { VUT Brno }\end{array}$ \\
\hline 2. & MS Wood processing cluster & 2005 & 30 & VŠB-TU Ostrava \\
\hline 3. & $\begin{array}{l}\text { Envicrack Cluster of alterna- } \\
\text { tive energy }\end{array}$ & 2006 & 28 & VŠB-TU Ostrava \\
\hline 4. & Hydrogen Cluster & 2006 & 11 & VŠB-TU Ostrava \\
\hline 5. & IT Cluster & 2006 & 50 & VŠB-TU Ostrava \\
\hline 6. & MS Automotive Cluster & 2006 & 52 & $\begin{array}{c}\text { VŠB-TU Ostrava, } \\
\text { UTB Zlín }\end{array}$ \\
\hline 7. & MS Energy Cluster & 2008 & 20 & VSS-TU Ostrava \\
\hline 8. & MS Tourism Cluster & 2008 & 35 & $\begin{array}{l}\text { Knowledge management } \\
\text { cluster (MS Construction } \\
\text { cluster 2009) }\end{array}$ \\
\hline 10. & Safety Technology Cluster & 2010 & 18 & VŠB-TU Ostrava \\
\hline
\end{tabular}

In a short period of seven years ten clusters were established in the region and they exhibit in most cases the growing number of its members.

\subsection{Financing Cluster Initiatives in Moravia Silesia}

The initial and very small financing for clusters identification in Moravia-Silesia region between 2003-2004 was given to cluster facilitators (UDMS, RDA) by Regional Moravian Silesian Authority in the amount of CZK 3 mil., the main sources were allocated from official cluster programmes financed by EU Structural funds supporting cluster development. The comparison of allocation in the Czech Republic and Moravian Silesian region is given in Table 5 from which follows the MS region received more than $28 \%$ of all funds. 
Tab.5 - Public aid for clusters in Moravia-Silesia Region. Source: Czechinvest, 2011

\begin{tabular}{|l|c|c|c|}
\hline \multirow{2}{*}{ Programme } & \multicolumn{2}{|c|}{ Public Aid (CZK mil.) } & \multirow{2}{*}{ MSR in \% } \\
\cline { 2 - 3 } & $\begin{array}{c}\text { Czech } \\
\text { Republic }\end{array}$ & $\begin{array}{c}\text { Moravia Silesia } \\
\text { Region }\end{array}$ & (20, \\
\hline I. CLUSTERS Search (2004-2006) & 31,6 & 6,2 & 19,6 \\
\hline I. CLUSTERS Establishment (2007-2008) & 199,1 & 62,7 & 31,5 \\
\hline II. COOPERATION (2009-2011) & 823,3 & 230,2 & 28,0 \\
\hline Total & 1054 & 299,1 & 28,4 \\
\hline
\end{tabular}

The establishment of first Czech cluster - Moravian Silesian Engineering cluster was the outcome of general clusters study in the region prepared in 2002 in a cooperation of CzechInvest, foreign EU experts, Faculty of economics of VSB-TU Ostrava and UDMS. Between the years 2004-2006 the VSB-TU Ostrava, UDMS and prepared 8 feasibility studies for cluster identification with total financing of CZK 6,2 mil. Based on these studies establishment of four other clusters followed in 2005-2006 (see Table 4). Already in 2007 the four new clusters applied and received subsidy for their development in a total amount of CZK 65,5 mil. They were Czech Machinery cluster, MS Automotive Cluster, MS Wood cluster and Envicrack Cluster. The overview of cluster financing in MS region is presented in Figure 2. Only three clusters did not receive any financial support from cluster programmes.

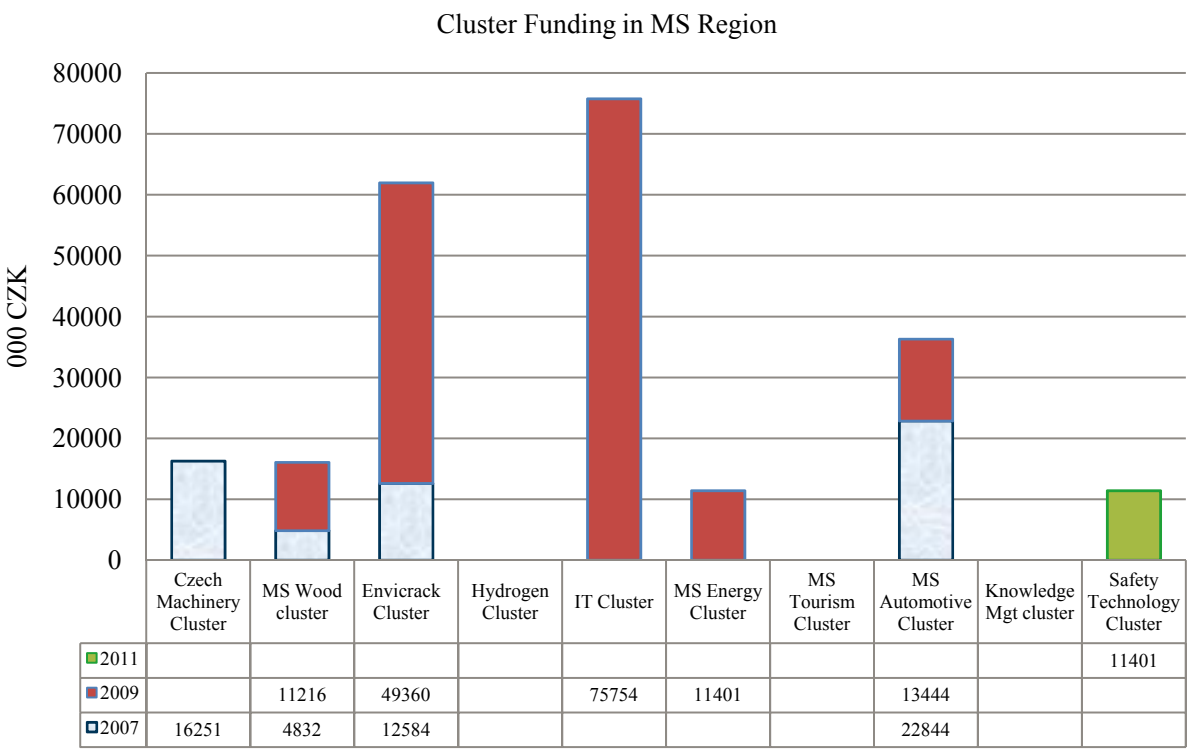

Fig. 2 - Financing clusters in Moravia-Silesia. Source:CzechInvest, 2011, own processing

In 2007 new programme COOPERATION for cluster financing was announced. In the first call in 2008 applied again and succeeded Envicrack, MS Automotive and MS Wood clusters followed by IT Cluster and a new MS Energy cluster. In the second call in 2010 applied and succeeded 
only newly established MS Safety Technology cluster. The amount of CZK 230 mil. of this programme were allocated to Moravian Silesian clusters.

\section{CONCLUSIONS}

The idea of regional industry clusters appeared in the Czech professional community only about ten years ago, however it was quickly accepted not only by academics mostly at regional universities but also by politicians at the government level in the Ministry of Industry and Trade. The result of this interest was the involvement of public aid for clusters in the first Operational Programme Industry and Enterprise in the sub-programme CLUSTERS in 2004-2006 in which the amount of CZK 230 mil. were allocated for cluster projects. Within this programme the support was given to the two types of projects. The first project type aimed at the search of clusters and identification of potential clusters in the regions. Here, CZK 32 mil. were given to 41 project applications which resulted in feasibility studies in 12 of the 13 eligible regions. In the second type of projects 12 established clusters in five regions received grants of CZK 199 mil. for their development. The leaders in cluster promotion became two regions - old industrial region Moravskoslezský which understood the support of clusters as a way of potential regional transformation and the innovating region Jihomoravský, which has seen in clusters the potential for the increase of innovation performance.

In the EU programme period 2007-2013 the public aid for clusters was incorporated in the Operational Programme Enterprise and Innovation governed again by the Ministry for Industry and Trade in the sub-programme COOPERATION together with the centres of excellence and technology platforms. In the two calls for projects in 2009-2010 total 23 cluster projects were supported by CZK 733 mil. The aid was again unevenly distributed between regions. The two above mentioned regions took the lead in cluster support with ten and nine clusters, Královéhradecký region with six supported cluster projects became the next one. The projects are focused mainly on innovation and competitiveness of cluster companies.

In a difference from generally accepted theory that clusters are business or industry driven the Czech case seems to be slightly different. The clusters here are "subsidies" initiated and only then business driven. By our opinion this was the public aid for cluster studies which initiated the interest of regional politicians, regional development agencies, innovation centres large and small and medium-sized enterprises for clusters and only then the following public subsidies determined the cluster development. Significant role also played the universities which saw in clusters the new field of research. Public aid and involvement of Triple Helix actors - government, academia and firms are the main cause of presented achievements in cluster development in the Moravian-Silesian region.

Out of ten clusters in Moravia-Silesia seven received the public aid for their development with a leading position of IT cluster, three cluster succeeded in two cluster programmes. However the subsidies presented here are not the only EU subsidies for clusters. The clusters can apply also for other EU funded programmes. As an example can serve MS Wood cluster which received within Operational programme education for competitiveness other subsidies of CZK 22 mil. The cluster subsidies stimulated their growth mainly in the first phase of cluster lifecycle.

As the clusters in the Czech Republic were established in most cases only in the last years it is 
not possible to make a thorough evaluation of their impact on the regional economies. However preliminary analyses and the field research indicate their positive role in the increase of innovative potential in regions, employment, the growth of social capital and strengthening the links between industry and academia. Generally the establishment of more than 40 clusters within the last five years can be considered as the success of top down approach and effective cluster policy.

\section{Acknowledgment}

This paper was prepared with the aid of Eurocores project GECRP/11/E025 Cluster life cycles, the role of actors, networks and institutions in emerging, growing, declining and renewing clusters and by SGS project of Faculty of Economics, VŠB-Technical University of Ostrava SP2012/153 Disparity, soudržnost a konkurenceschopnost v zemích a regionech Visegrádské čtyřky v kontextu vybraných vyspělých zemí EU.

\section{References}

1. Adámek, P. et. al. (2009). Evaluation of the absorption capacity of Operational Programme Enterprise and Innovation 2007 - 2013 in relation to target group. Prague: MIT, Bermann Group.

2. Bialic-Davendra, M.L. (2011). Proposal of a framework. for a cluster development in the selected Central-European countries. Doctoral Thesis. Zlín: Tomas Bata University.

3. CzechInvest. (2011). OPEI Statistics (Statistika čerpání dotací z OPPI). Retrieved from [30 July 2011]: http://eaccount.czechinvest.org/Statistiky/StatistikaCerpaniDotaci.aspx.

4. European Commission (2005). Final report of the Expert Group on Enterprise Clusters and Networks. Brussels: European Commission, Enterprise DG.

5. European Commission (2007). A statistical analysis and overview of current policy support. Luxembourg: Office for Official Publications of the European Communities.

6. European Commission (2008). Clusterpolicy in Europe. Kristiansand: Oxford Research AS.

7. European Commission (2010). White Paper. The Emerging of European World-Class Clusters. Brussels: Europa InterCluster.

8. Kovárník, J. \& Stejskal, J. (2009). Klastry jako nástroj regionálního inovačního profilu. Scientific Papers of the University of Pardubice. Series D. Special Edition. 2009, 52-56.

9. Marshall, A. (1920). Principles of Economics. London: Macmillan.

10. Martin, R. \& Sunley, P. (2003). Deconstructing Clusters: Chaotic Concept or Policy Panacea? In: Journal of Economic Geography, 3 (1), 5-35.

11. Martin, P., Mayer, T. \& Mayneris, F. (2011). Public support to clusters. A firm level study of French "Local Productive Systems". Regional Science and Urban Economics, 41 (2), 108-123.

12. McDonald F., Dimitrios T. \& Huang Q. (2006). The development of industrial clusters and public policy. Entrepreneurship \& Regional Development: An International Journal, 18 (6), 525-542.

13. MIT (2003). Operational Programme Enterprise and Innovations (OPEI) 2007-2013. Prague: MIT.

14. MIT (2010). Operational Programme Industry and Enterprise (OPIE) 2004-2006. Prague: MIT.

15. OECD (2007). Competetive Regional Clusters. National Policy Approaches. Paris: OECD Publishing.

16. Pavelková, D. \& Jirčíková, E. (2008). Klastry jako nástroj zvýšení konkurenceschopnosti firem. E\&M Ekonomie a Management, 11 (3), 62-71.

17. Pavelková, D. et. al. (2009). Klastry a jejich vliv na výkonnost firem. Praha: Grada. 
18. Porter, M. E. (1990). The Competitive Advantage of Nations. New York: The Free Press.

19. Skokan, K. (2002). Industry Clusters v regionálním rozvoji. Ekonomická revue, 5 (2), 50 - 60.

20. Skokan, K. (2004). Konkurenceschopnost, inovace a klastry. Ostrava: Repronis.

21. Skokan, K. (2011). Financing the Cluster Development in Moravia Silesia by EU Funds. In Financial management of firms and financial institutions - Proceedings of International Conference. Ostrava: VSB-TU Ostrava.

22. Skokan, K. \& Poledníková, E. (2011). Public Aid for Clustering Firms in the Cžech Regions. In Finance and the performance of firms in science, education, and practice. Proceedings of the $5^{\text {th }}$ International Scientific Conference (423-432). Zlín: Tomas Bata University in Zlin.

23. Sölvell, Ö., Lindqvist, G. \& Ketels, C. (2003). The Cluster Initiative Greenbook. Stockholm: Ivory Tower AB.

24. Sölvell, Ö., Ketels, Ch. \& Lindqvist, G. (2011). EU Cluster Mapping and Strengthening Clusters in Europe. Luxembourg: Publications Office of the European Union. http://dx.doi. org/10.2769/10419

25. Suchacek, J. (2005). Restructuring of Traditional Industrial Regions in Transitive Economies (Restrukturalizace tradičnich prümyslových region v tranzitivnich ekonomikách). Ostrava: VSB-Technical University.

26. Szekely, V. (2008). Regional industrial clusters and problems (not only) with their identification. Ekonomický časopis, 56 (3), 223 - 238.

27. Šimon, M. (2005). Clusters and their role in the new knowledge economy. Applied Computer Science, 1 (1), 43-61.

28. Viturka, M. (2007). Konkurenceschopnost regionů a možnosti jejího hodnocení. Politická ekonomie. 55 (5), 637-658.

29. Thorburn, A., Botham, R. \& Skokan, K. (2002). Feasibility Study to Identify Industry Groupings in Moravia-Silesia for Targeted Aid Scheme Support. Prague: CzechInvest.

30. Žižka, M. (2004). Metody identifikace klastrů. E+M Ekonomie a Management, 7 (4), 32 - 46.

\section{Contact information}

prof. Ing. Karel Skokan, Ph.D.

$\checkmark \stackrel{S}{\text { B }}$ Technical University Ostrava,

Faculty of Economics

Sokolská trída 33, 70121 Ostrava 1, Czech Republic

Tel: +420 597322230

Email:karel.skokan@vsb.cz.

Ing. Eva Poledníková

$V S ̌ B$ Technical University Ostrava,

Faculty of Economics

Sokolská trída 33, 70121 Ostrava 1, Czech Republic

Tel: +420 597322230

Email:eva.polednikova.st1@vsb.cz.
Ing. Michaela Stanícková

Vঙ̌B Technical University Ostrava,

Faculty of Economics

Sokolská trída 33, 70121 Ostrava 1,

Czech Republic

Tel: +420 597322230

Email: michaela.stanickova.st@vsb.cz. 